\title{
Low-dose testosterone treatment decreases oxidative damage in TM3 Leydig cells
}

\begin{abstract}
Thomas IS Hwang ${ }^{1,2,3}$, Tien-Ling Liao ${ }^{4}$, Ji-Fan Lin ${ }^{5}$, Yi-Chia Lin ${ }^{2,3}$, Shu-Yu Lee ${ }^{4}$, Yen-Chun Lai ${ }^{4}$ and Shu-Huei Kao ${ }^{4}$
Testosterone replacement therapy has benefits for aging men and those with hypogonadism. However, the effects of exogenous testosterone on Leydig cells are still unclear and need to be clarified. In this report, we demonstrate that testosterone supplementation can reduce oxidative damage in Leydig cells. The TM3 Leydig cell line was used as an in vitro cell model in this study. Cytoprotective effects were identified with $100-\mathrm{nmol}^{-1}$ testosterone treatment, but cytotoxic effects were found with $\geqslant 500-\mathrm{nmol}^{-1}$ testosterone supplementation. Significantly reduced reactive oxygen species (ROS) generation, lipid peroxide contents and hypoxia induction factor (HIF)-1 $\alpha$ stabilization and activation were found with $100-\mathrm{nmol} \mathrm{I}^{-1}$ testosterone treatment. There was a 1.72-fold increase in ROS generation in the $500-\mathrm{nmol} \mathrm{I}^{-1}$ compared to the $100-\mathrm{nmol} \mathrm{I}^{-1}$ testosterone treatment. A 1.58 -fold increase in steroidogenic acute regulatory protein (StAR) expression was found in $50-\mathrm{nmol} \mathrm{I}^{-1}$ testosterone-treated cells $(\boldsymbol{P}<0.01)$. Chemically induced hypoxia was attenuated by testosterone supplementation. Leydig cells treated with low-dose testosterone supplementation showed cytoprotection by decreasing ROS and lipid peroxides, increasing StAR expression and relieving hypoxia stress as demonstrated by HIF-1 $\alpha$ stabilization. Increased oxidative damage was found with $\geqslant 500-\mathrm{nmol} \mathrm{I}^{-1}$ testosterone manipulation. The mechanism governing the differential dose effects of testosterone on Leydig cells needs further investigation in order to shed light on testosterone replacement therapy.
\end{abstract}

Asian Journal of Andrology (2011) 13, 432-437; doi:10.1038/aja.2010.159; published online 7 February 2011

Keywords: Leydig cells; oxidative damage; reactive oxygen species; testosterone

\section{INTRODUCTION}

Testosterone plays an important role in normal growth and development of male sex organs. It is also known to be a key player in glucose homeostasis and lipid metabolism. ${ }^{1}$ More recently, gonadotrophinreleasing hormones I and II were demonstrated to stimulate testosterone production in murine Leydig cells. ${ }^{2}$ In the testes, Leydig cells synthesize and secrete testosterone in response to luteinizing hormone, which is counter-regulated by feedback influences of testosterone and its metabolites. Testosterone levels notably decline with aging, ${ }^{3,4}$ however, a recent report showed no correlation between androgen receptor (AR) polymorphism and the serum concentrations of total and free testosterone in elderly men. ${ }^{5}$ The mechanism by which aged Leydig cells lose their steroidogenic function remains unclear. It was proposed that decreases in testosterone levels with aging may reflect reactive oxygen species (ROS) elevation and further disruption of the ability of Leydig cells to produce testosterone. ${ }^{6,7}$

Mitochondrial respiration, which typically consumes about $90 \%$ of the oxygen utilized by cells, is considered to be the major source of cellular ROS. ${ }^{8}$ ROS cause tissue damage by a variety of mechanisms including DNA damage, lipid peroxidation, protein oxidation and carbonylation, depletion of cellular thiols and activation of proinflammatory cytokine release. Mitochondrial-derived ROS were implicated in a number of disease and disorders, including neurodegenerative diseases, cancers, ischemia/reperfusion injury and infertility. ${ }^{9,10}$
The aging process leads to the physiological lowering of androgen levels including testosterone. The effect of testosterone on men's health has sparked interest in the issue of androgen replacement. ${ }^{11}$ Men with primary hypogonadism (congenital or acquired) or hypogonadotropic hypogonadism are candidates for testosterone replacement therapy. ${ }^{12}$ Testosterone therapy in aging males was suggested to improve the body composition and certain domains of brain function as well as decreasing cardiovascular risks. Potential risks include erythrocytosis, edema, gynecomastia, prostate stimulation and suppression of sperm production. The possibility of an increased risk of clinically significant prostate cancer was considered. ${ }^{13}$ Testicular size and consistency often diminish, and men should be advised that fertility will be greatly compromised during testosterone therapy because of the downregulation of gonadotropins. ${ }^{12}$ Moreover, a clinical overdose replacement of testosterone or abuse needs to be monitored.

It is well known that the use of exogenous testosterone supplementation decreases gonadotropin synthesis and intratesticular testosterone in vivo. In addition to the central effect (along the hypothalamus-pituitary-testis axis), the peripheral effect of exogenous testosterone on Leydig cells has not been clarified. Our study used low-dose $\left(100 \mathrm{nmol}^{-1}\right)$ testosterone treatment in vitro in order to mimic local effects of testosterone on Leydig cells. Successful management of testosterone replacement therapy requires an appropriate evaluation and an understanding of the benefits and risks of treatment. 
In this study, we propose that testosterone therapy prevented cells from oxidative stress-induced damage and cell death; moreover, we explored the beneficial effects (cell viability and steroidogenesis) and potential risks (ROS generation, lipid peroxidation and hypoxic stress) of testosterone supplementation using the TM3 Leydig cell line as an in vitro cell model.

\section{MATERIALS AND METHODS}

\section{Cell culture and preparation}

The TM3 cell line (ATCC no. CRL-1714; ATCC, Manassas, VA, USA) was selected as the cell model in this study. This cell line was established from Mus musculus (mouse) and was characterized by the AR. Chemicals and medium were purchased from Sigma-Aldrich (St Louis, MO, USA). Since testosterone may affect Leydig cells by inducing the conversion to estradiol, we carried out all experimental procedures in growth medium using phenol red-free, serum-free culture medium and with the estrogen receptor antagonist, ICI 182780 (Tocris Cookson, Balliwell, MO, USA), to avoid the bioeffects of phenol red, serum and estradiol. The TM3 cell line was cultured in medium with a $1: 1$ mixture of phenol red-free Ham's F12 medium and phenol red-free Dulbecco's modified Eagle's medium with $4.5 \mathrm{~g} \mathrm{l}^{-1}$ glucose, $1.2 \mathrm{~g} \mathrm{l}^{-1}$ sodium bicarbonate, $15 \mathrm{mmol} \mathrm{l}^{-1}$ HEPES, $100 \mathrm{nmol} \mathrm{l}^{-1}$ of ICI 182780 and $5 \%$ fetal bovine serum (Gibco, Invitrogen, Grand Island, NY, USA). For testosterone supplementation studies, testosterone (Organon, Oss, The Netherlands) was administered at the doses of 10, 50, 100, 500, 1000 and $2000 \mathrm{nmol}^{-1}$. For time-related studies, testosterone was administered at a dose of $100 \mathrm{nmol} \mathrm{l}^{-1}$ for $6,8,12,24,36$ and $48 \mathrm{~h}$.

\section{Cell viability}

Trypan blue exclusion. TM3 cells were plated in 12-well plates at a density of $\left(2 \times 10^{5}-5 \times 10^{5}\right.$ cells/well $)$ and grown for $24 \mathrm{~h}$. Different concentrations of testosterone were added to cells, while only alcohol (solvent) was added to the control group. Cells were grown at $37^{\circ} \mathrm{C}$ in $5 \% \mathrm{CO}_{2}$ and $95 \%$ air for $24 \mathrm{~h}$. Briefly, approximately $10 \mu \mathrm{l}$ of a cell suspension in phosphate-buffered saline was mixed with $40 \mu \mathrm{l}$ of trypan blue, and the numbers of stained (dead cells) and unstained cells (live cells) were counted using a hemocytometer.

3-(4', $5^{\prime}$-dimethylthiazolyl-2)-2,4-diphenyltetrazolium bromide (MTT) cell viability assay. The yellow tetrazolium salt, MTT, is metabolized by mitochondrial succinic dehydrogenase activity of proliferating cells to yield a purple formazan reaction product. In brief, $200-\mu \mathrm{l}$ aliquots of suspensions of $2 \times 10^{4}$ testosterone-treated cells were placed into wells of microtiter plates. Untreated cells were utilized as controls for non-specific dye reduction. After incubation at $37{ }^{\circ} \mathrm{C}$ for different time periods in a humidified $5 \% \mathrm{CO}_{2}$ atmosphere, the plates were spun at $700 \mathrm{~g}$, the supernatants were discarded and $20 \mu \mathrm{l}$ of the $10 \mu \mathrm{mol}{ }^{-1}$ MTT solution was added to each well. After an additional hour of incubation, $150 \mu \mathrm{l}$ of dimethyl sulfoxide was added to the wells to extract the formazan. The formazan absorbance was measured at $565 \mathrm{nmol}^{-1}$, and values represent the optical density per mg of protein.

\section{Estimation of ROS production}

ROS production was detected with $2^{\prime}, 7^{\prime}$-dichlorodihydrofluorescein diacetate $\left(\mathrm{H}_{2} \mathrm{DCFDA}\right)$ (Molecular Probes, Eugene, OR, USA). Cells were plated on 48 -well plates at an initial density of $2 \times 10^{4}$ treated cells per well and grown for 3 days. After cells were $90 \%$ confluent, they were washed three times with Hank's balanced salt solution. Following the addition of $10 \mu \mathrm{mol} 1^{-1} \mathrm{H}_{2} \mathrm{DCFDA}$ (final concentration), the appearance of DCF fluorescence was typically followed for $1 \mathrm{~h}$, using excitation at $486 \mathrm{nmol}^{-1}$ and emission at $530 \mathrm{nmol}^{-1}$. The fluorescence profiles were quantified using the LYSYS II software program (Becton Dickenson, Franklin Lakes, NJ, USA).

\section{Determination of lipid peroxide}

In each analytical run, a reagent blank, 1,1,3,3-tetraethoxypropane standard working solutions, and the sample were assayed in duplicate. An aliquot of $50 \mu \mathrm{l}$ of each sample was pipetted into a test tube containing $0.6 \mathrm{ml}$ of $0.44 \mathrm{~mol}^{-1}$ phosphoric acid. After mixing, $0.2 \mathrm{ml}$ of $42-\mathrm{mmol}^{-1}$ thiobarbituric acid solution was added to a final concentration of $7 \mathrm{mmol} \mathrm{l}^{-1}$ and then placed in a $95^{\circ} \mathrm{C}$ dry bath for $1 \mathrm{~h}$. Samples were then cooled and neutralized with $1 \mathrm{~mol}^{-1} \mathrm{NaOH}$ in methanol before the high-performance liquid chromatographic analysis. An aliquot of $20 \mu \mathrm{l}$ of supernatant obtained above was injected into a narrow-pore $\mathrm{C}_{18}$ column $\left(4.6 \times 250 \mathrm{mmol} \mathrm{l}^{-1}\right.$, with a particle size of $5 \mu \mathrm{mol}^{-1}$ ) using a Jasco PU-980 pump (Jasco, Tokyo, Japan) with a solvent system composed of methanol and $50 \mathrm{mmol} \mathrm{l}^{-1}$ phosphate buffer $(\mathrm{pH} 6.8)(4: 6, \mathrm{v} / \mathrm{v})$ at a flow rate of $1 \mathrm{ml} \mathrm{min}^{-1}$. The eluent was monitored with a Jasco fluorescence detector (with excitation at $525 \mathrm{nmol} \mathrm{l}^{-1}$ and emission at $550 \mathrm{nmol} \mathrm{l}^{-1}$ ).

\section{Preparation of total RNA and reverse transcription (RT)}

The steroidogenic acute regulatory (StAR) protein is the key enzyme in steroidogenesis. In order to demonstrate the effect of testosterone on intracellular steroidogenesis, alterations in StAR messenger RNA (mRNA) and $A R$ mRNA were detected. Testosterone-treated cells were lysed by adding $2 \mathrm{ml}$ of a guanidium thiocyanate phenol RNAzol B solution (Biotex, Houston, TX, USA). Chloroform was added to the homogenate, and the mixture was allowed to stand on ice (or at $4{ }^{\circ} \mathrm{C}$ ) for $15 \mathrm{~min}$. The RNA fraction was collected and precipitated with isopropanol. The RNA pellet was collected and resuspended in diethylpyrocarbonate-treated water. The RT master mixture was prepared by adding $200 \mu \mathrm{mol} \mathrm{l}^{-1}$ of each dNTP, 0.5 units of rTth DNA polymerase, $50 \mathrm{pmol}$ of Oligod(T)12-18, $10 \mathrm{mmol} \mathrm{l}^{-1}$ Tris- $\mathrm{HCl}(\mathrm{pH} 8.3)$ and $90 \mathrm{mmol} \mathrm{l}^{-1}$ $\mathrm{KCl}$. RT was carried out in $20 \mu \mathrm{l}$ of the above mixture at room temperature for $10 \mathrm{~min}$, at $42{ }^{\circ} \mathrm{C}$ for $10 \mathrm{~min}$ and then at $70{ }^{\circ} \mathrm{C}$ for $2.5 \mathrm{~min}$.

\section{Real-time PCR}

Following RT, complementary (c)DNA was applied in a fluorescencebased real-time polymerase chain reaction (PCR) to determine alterations in StAR and AR mRNA expressions in testosterone-treated cells. To determine StAR and AR mRNA contents relative to $\beta$-actin mRNA, the forward primer 5'-CGTGGGCCGCCCTAGGCAACCA-3' and the reverse primer 5'-TGGTGGCCTAGGGCGGCCCACG-3' were used for the $\beta$-actin gene. For the analysis of StAR, the forward primer 5'CTGGTTGATGATTGTCTTCGGC-3' and the reverse primer 5'GCCGAAGACAATCATCAACCAG-3' were used to amplify a 511bp PCR product. For analysis of the AR, the forward primer 5'GAGGAACAGCAGCCTTCACAGCAGC-3' and reverse primer 5'GCTGCTGTGAAGGCTGCTGTTCCT-3' were used to amplify a 386-bp PCR product. The PCR was performed in a Roche Light Cycler apparatus (Roche, Manheim, Germany), using the Faststart DNA Master SYBR Green Kit. Reactions were performed as follows: initial denaturation at $95{ }^{\circ} \mathrm{C}$ for $300 \mathrm{~s}$ followed by 40 cycles of $1 \mathrm{~s}$ at $95^{\circ} \mathrm{C}, 6 \mathrm{~s}$ at $58^{\circ} \mathrm{C}$ and $18 \mathrm{~s}$ at $72{ }^{\circ} \mathrm{C}$. The threshold cycle number $\left(C_{\mathrm{t}}\right)$ values of the $\beta$-actin, StAR and AR genes were determined for each individual quantitative PCR run. The - $\operatorname{ddCt}$ (StAR and $A R$ genes to $\beta$ actin gene) represents the content in a cell. Each measurement was carried out at least three times and normalized in each experiment against a serial dilution series of a control DNA sample. 


\section{Western blotting}

After chemical induction of hypoxia with $100 \mu \mathrm{mol} \mathrm{l}^{-1} \mathrm{CoCl}_{2}$, whole-cell lysates were taken directly from samples in extract buffer $\left(50 \mathrm{mmol} \mathrm{l}^{-1}\right.$ Tris (pH 7.4), $150 \mathrm{mmol}^{-1} \mathrm{NaCl}, 5 \mathrm{mmol} \mathrm{l}^{-1}$ EDTA, $0.1 \%$ sodium dodecylsulfate, $1 \mathrm{mmol}^{-1}$ phenazine methosulfate and complete protease inhibitor). Equal amounts of protein were electrophoresed on an acrylamide gel, transferred to a nitrocellulose membrane (Bio-Rad, Hercules, CA, USA) and blocked with 5\% non-fat dry milk in Trisbuffered saline with $0.1 \%$ Tween 20 . Rabbit anti-hypoxia induction factor (HIF)-1 $\alpha$ (Santa Cruz Biotechnology, Santa Cruz, CA, USA) was used at a 1:5000 dilution and detected by a 1:2000 dilution of a horseradish peroxidase-conjugated anti-rabbit secondary antibody (Jackson ImmunoResearch, West Grove, PA, USA) followed by enhanced chemiluminescence detection (Amersham Biosciences, Uppsala, Sweden).

\section{Statistical analysis}

We employed a paired $t$-test analysis to determine the significance between cells with and without testosterone treatment. $P<0.05$ was considered significant.

\section{RESULTS}

\section{Cell viability of testosterone-manipulated cells}

Increased cell viability was found in low-dose testosterone-treated cells ( $\leqslant 100$-nmoll $1^{-1}$ testosterone) by dye exclusion and the MTT assay. In the dye-exclusion test, the viability was $71.0 \% \pm 5.6 \% \quad(n=5, P<0.005)$ (mean \pm sd), $92.3 \% \pm 5.3 \%, \quad 96.8 \% \pm 2.9 \% \quad(P<0.05), \quad 68.4 \% \pm 2.2 \%$ $(P<0.005$, compared with the control) and 56.2\% $\pm 6.1 \%(P<0.001$, compared with the control) in the control, and 50, 100, 500, 1000 and $2000 \mathrm{nmol} \mathrm{l}^{-1}$ testosterone-supplemented groups, respectively (Figure 1a). In the MTT assay, the viability was calculated based on intracellular succinate dehydrogenase activity. The viability of $100-$ nmol $~^{-1}$ testosterone-treated cells was $120.8 \% \pm 3.6 \%$ ( $n=5, P<0.005$, compared with the control) by the MTT assay. However, a decline in viability was detected at higher doses (Figure 1a). The cytotoxic effect was found in $\geqslant 500-\mathrm{nmol} \mathrm{l}^{-1}$ testosterone-treated TM3 cells. In addition, a cytoprotective effect was found in $100-\mathrm{nmol}^{-1}$ testosterone-treated cells for different time periods of $8-48 \mathrm{~h}$. Cell viability was $126.3 \% \pm 3.9 \%$ ( $n=5, P=0.0001$, compared with the control) in the group supplemented with $100-\mathrm{nmol} \mathrm{l}^{-1}$ testosterone for $36 \mathrm{~h}$ (Figure $\mathbf{1 b}$ ). To test whether the cytoprotective effect is specific for testosterone, we further investigated the effect of an inert steroid, epitestosterone, on cell viability. In

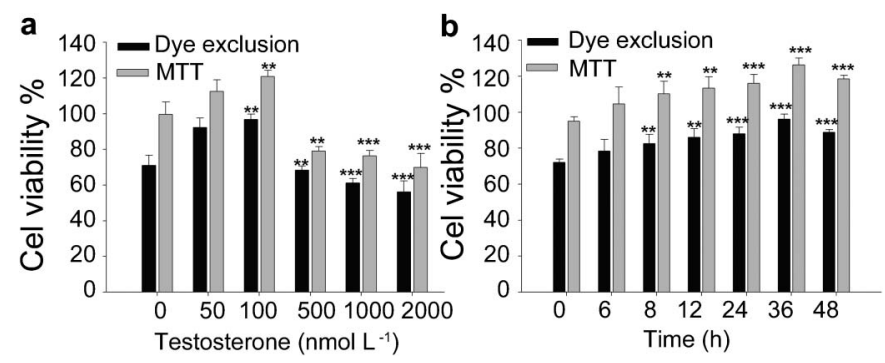

Figure 1 Dose-response and time-dependent effects of testosterone on the viability of TM3 cells. Cell viability was detected by a dye exclusion method (black bar) and MTT assay (gray bar). (a) Cells were incubated with testosterone at $37^{\circ} \mathrm{C}$ for $48 \mathrm{~h}$. A decline in cell viability was shown in cells treated with $\geqslant 500-\mathrm{nmol} \mathrm{I}^{-1}$ testosterone. (b) Cells were incubated with $100-\mathrm{nmol} \mathrm{I} \mathrm{I}^{-1}$ testosterone at $37^{\circ} \mathrm{C}$ for various time periods, and then the cell viability was determined. Four independent experiments were carried out in this study. Plots are presented as mean \pm s.d. $(n=5) . * P<0.05, * * P<0.01$ and $* * * P<0.001$ compared to the control. MTT, 3-(4',5'-dimethylthiazolyl-2)-2,4-diphenyltetrazolium bromide. brief, no obvious cell death was found in the epitestosterone-treated cells ranging from $50 \mathrm{nmol}^{-1}$ to $500 \mu \mathrm{mol} \mathrm{l}^{-1}$. A $10.2 \%$ reduction of cell viability was achieved in the $100-\mathrm{nmol}^{-1}$ epitestosterone-treated cells at $48 \mathrm{~h}(P<0.01$, data not shown).

\section{Decreased ROS generation and lipid peroxides in low-dose testosterone-treated cells}

After $\mathrm{H}_{2}$ DCFDA staining and a flow cytometric analysis, the MFI was $0.70 \pm 0.02$ ( $n=5, P<0.01$, compared with the control) for 100nmol $l^{-1}$ testosterone-treated cells, and was $1.21 \pm 0.10(n=5, P<0.05$, compared with the control) for $\geqslant 500-\mathrm{nmol} \mathrm{l}^{-1}$ testosterone-treated TM3 cells (Figure 2a and c). Reduced ROS generation was found in 50 and $100 \mathrm{nmol}^{-1}(P<0.05$ and $P<0.01$, respectively) testosteronetreated cells, and an opposite result was found in $\geqslant 500-\mathrm{nmol} 1^{-1}$ testosterone-treated TM3 cells (Figure 2b). Following highperformance liquid chromatographic fluorescent detection of thiobarbituric acid-reacted lipid peroxides, a decrease in lipid peroxides was detected in $100-\mathrm{nmol}^{-1}$ testosterone-treated cells $(1.56 \pm 0.19$ pmol per $\mu \mathrm{g}$ protein, $n=5, P<0.005$ ) (Figure $2 \mathbf{b}$ ), but an increase in lipid peroxides was detected in the $500-\mathrm{nmol} 1^{-1}$ testosterone-supplemented group (2.83 $\pm 0.16 \mathrm{pmol}$ per $\mu \mathrm{g}$ protein, $P=0.035$ ) (Figure $2 \mathbf{b}$ ). Declines in ROS generation and lipid peroxide contents were also detected in 100-nmol $1^{-1}$ testosterone-treated cells in a time-dependent manner, which revealed the lowest level at $36 \mathrm{~h}(1.37 \pm 0.05, P=0.0001)$ (Figure 2d). We also investigated the ROS generation in cells upon epitestosterone treatment. ROS reduction was found in cells treated with epitestosterone ranging from $50 \mathrm{nmol} \mathrm{l}^{-1}$ to $500 \mu \mathrm{mol} \mathrm{l} \mathrm{l}^{-1}$, especially in $100 \mathrm{nmol} \mathrm{l}^{-1}, 500 \mathrm{nmol}^{-1}$ and $1 \mu \mathrm{mol} \mathrm{l}^{-1}$. However, a timedependent enhancement of ROS generation was found in the cells treated with $10-\mu \mathrm{mol}^{-1}$ epitestosterone (data not shown). Therefore, both testosterone and epitestosterone can reduce ROS generation, but high dose of epitestosterone did not cause cell death in TM3 cells.

\section{Induced StAR protein and AR mRNA expressions in low-dose testosterone-treated cells}

Expression of the key enzyme in steroidogenesis, StAR, was detected by a real-time PCR. A 1.58-fold increase in StAR expression was found in $50-\mathrm{nmol}^{-1}$ testosterone-treated cells $(1.58 \pm 0.05, P<0.01)$ and a 1.42 -fold increase in $100 \mathrm{nmol}^{-1}$-treated cells $(1.42 \pm 0.06, P<0.01)$, but it was reduced to $69.2 \%$ in $1000 \mathrm{nmoll}^{-1}$ testosterone-treated cells $(0.79 \pm 0.06, P<0.05)$ (Figure 3a). A reduction in the StAR protein was suggested to cause a decline in steroidogenesis. In addition, a 1.26-fold increase in AR expression was found in cells with reduced ROS generation treated with low-dose $\left(100 \mathrm{nmoll}^{-1}\right)$ testosterone $(1.26 \pm 0.05$, $P<0.01$ ), but levels were closed to original ones following higher-dose testosterone supplementation (Figure $3 \mathbf{b}$ ).

\section{Decreased hypoxia in TM3 cells with low-dose testosterone supplementation}

Attenuated hypoxic stress was found in low-dose testosterone-manipulated cells. In this study, we exposed cells to hypoxic conditions by treating cells with or without the hypoxia-mimicking chemical, $\mathrm{CoCl}_{2}$, for $2 \mathrm{~h}$. Following the chemical induction of hypoxia, intracellular HIF$1 \alpha$ stabilization and activation increased to $132 \% \pm 3 \% \quad(P<0.05)$ without testosterone supplementation compared to the control group (without $\mathrm{CoCl}_{2}$ or testosterone treatment). After testosterone supplementation, $\mathrm{CoCl}_{2}$-induced HIF- $1 \alpha$ stabilization was reduced to $78 \%$ in $100-\mathrm{nmol} 1^{-1}$ testosterone-treated cells $(0.79 \pm 0.05, P<0.05$, Figure $4 a)$. Time-dependent decreases in HIF- $1 \alpha$ stabilization and activation were detected in 100-nmol $1^{-1}$ testosterone-treated cells (Figure $\mathbf{4 b}$ ). 

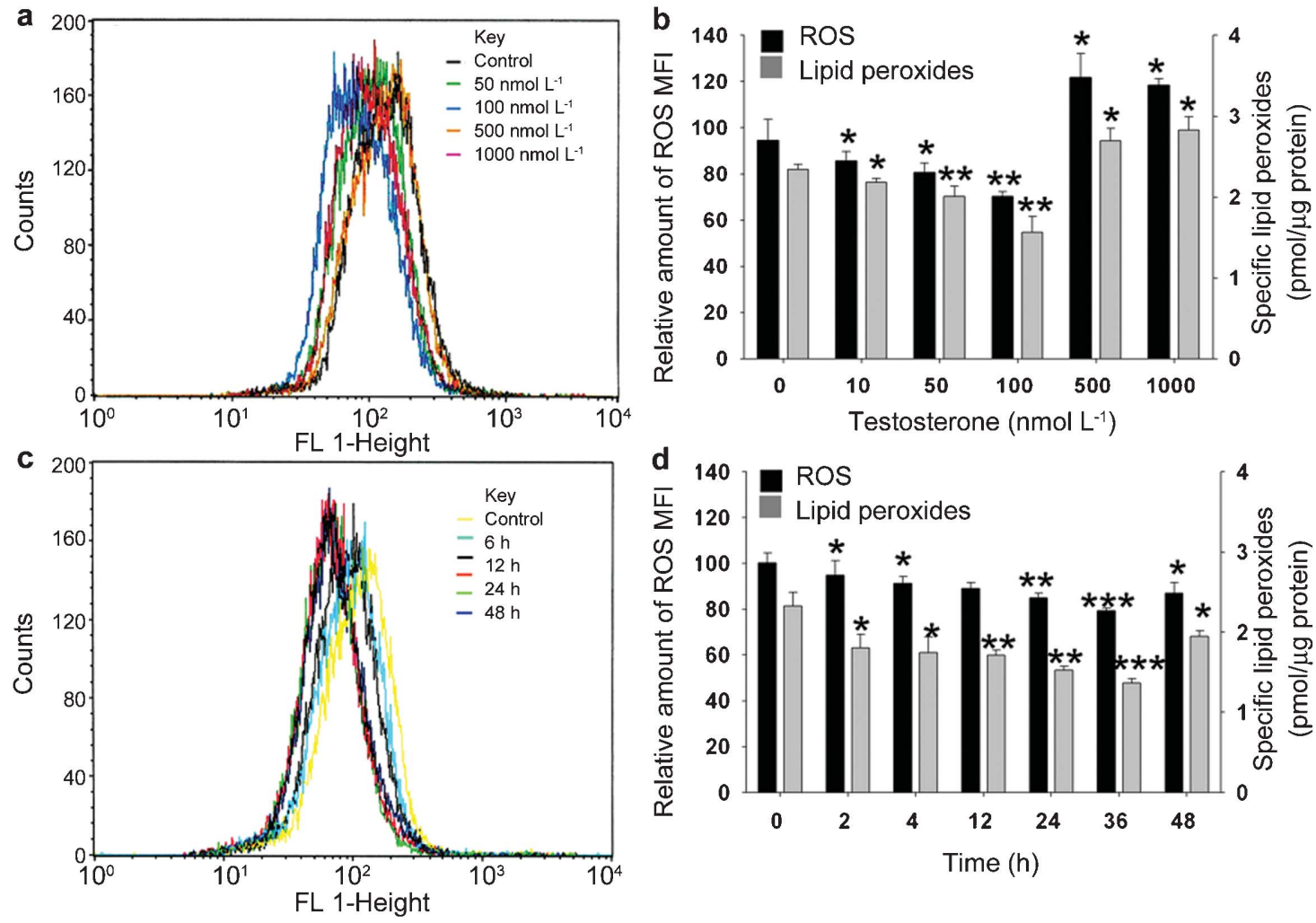

Figure 2 Dose- and time-dependent effects of testosterone on ROS generation and lipid peroxidation in TM3 cells. Staining with $\mathrm{H}_{2}$ DCFDA to check ROS generation revealed a left shift of the histogram in 100-nmol I-1 testosterone-treated cells (a, $\mathbf{c})$. The relative amounts of ROS production are shown as the ROS MFI. In $\mathbf{a}$ and $\mathbf{b}$, reduced ROS generation (MFI) and lipid peroxide were seen in cells treated with $100 \mathrm{nmol} \mathrm{I} \mathrm{I}^{-1}$, but these increased at higher doses ( $\geqslant 500-\mathrm{nmol} \mathrm{I}^{-1}$ testosterone). In $\mathbf{c}$ and d, time-dependent declines in ROS production and lipid peroxidation were shown in testosterone-treated cells. Plots are presented as mean $\pm s d(n=5) . * P<0.05$, $* * P<0.01$ and $* * * P<0.001$ compared to the control. $\mathrm{H}_{2}$ DCFDA, $2^{\prime}, 7^{\prime}$-dichlorodihydrofluorescein diacetate; MFI, mean fluorescence index; ROS, reactive oxygen species.

\section{DISCUSSION}

Testosterone therapy is being increasingly used in the management of male aging and postmenopausal women. ${ }^{14,15}$ Based on known androgen actions, the great benefits lie in improvements in muscle, fat, and bone mass and function. Recently, testosterone was reported to enhance apoptosis-related damage in human vascular endothelial cells ${ }^{16}$ and renal tubular cells. ${ }^{17}$ Testosterone was also demonstrated to induce fully reversible azoospermia in normal men. ${ }^{18}$ Contrarily, testosterone was reported to protect cerebellar granule cells from oxidative stress-induced cell death through a receptor-mediated mechanism. ${ }^{19}$ Conflicting findings reveal the need to address molecular signaling pathways with testosterone supplementation. a
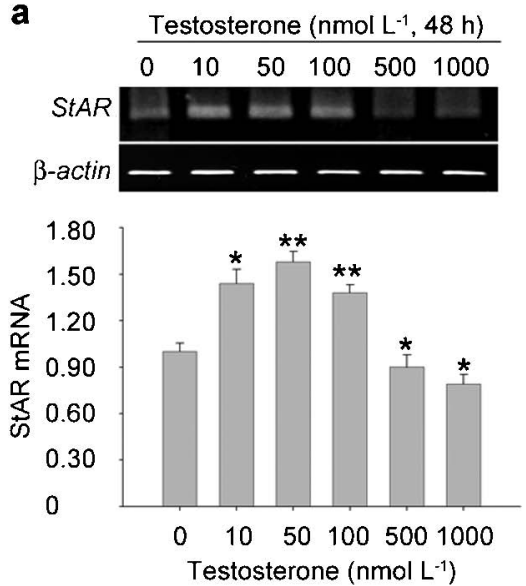

b
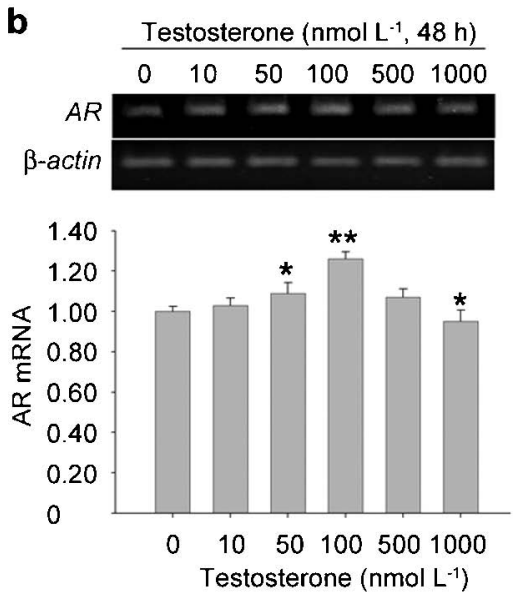

Figure 3 Alterations of StAR and AR mRNA expressions in testosterone-treated TM3 cells. mRNA was isolated, and an RT-PCR and real-time PCR were performed. Upper panels, electrophoretograms of RT-PCR of the StAR (a) and $A R(\mathbf{b})$ genes. Lower panel, quantification of StAR and $A R$ CDNA by real-time PCR. Plots are presented as mean \pm s.d. $(n=3) ; * P<0.05$ and $* * P<0.01$ compared to the control. AR, androgen receptor; $P C R$, polymerase chain reaction; RT, reverse transcription; StAR, steroidogenic acute regulatory protein. 

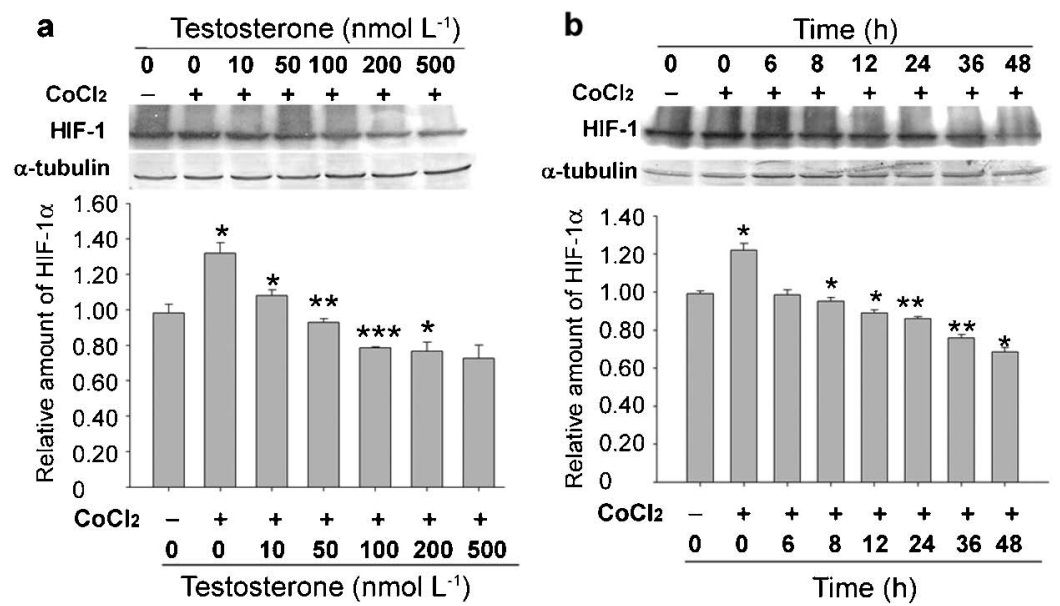

Figure 4 Attenuated $\mathrm{CoCl}_{2}$-induced HIF-1 $1 \alpha$ stabilization in 100-nmol $\mathrm{I}^{-1}$ testosterone-treated TM3 cells. Cells were incubated with testosterone at $37{ }^{\circ} \mathrm{C}$ for $48 \mathrm{~h}$, and then HIF- $1 \alpha$ stabilization was examined by a western blot analysis. Equal loading in each lane was demonstrated by the similar intensities of $\alpha$-tubulin. A dose-dependant (a) and a time-dependant (b) responses were shown. Mean densitometry data from independent experiments were normalized to the result obtained in cells in the absence of testosterone (control). Plots are presented as mean \pm s.d. ( $n=3) ; * P<0.05$ and $* * P<0.01$ compared to the control. HIF, hypoxia induction factor.

Parvinen et al. showed that labeled testosterone, pregnenolone and progesterone administered intravenously can penetrate the seminiferous tubules of rats within $2-5$ min. $^{20}$ The presence of a small amount of isotope within the tubules indicated that the blood-testis barrier did not completely exclude androgen from mouse testes. The steroid may act on Leydig cells, which are the predominant site of biosynthesis of testosterone. It was suggested that androgen's action upon these cells may be required for the maintenance of their steroid-synthesizing enzymes. ${ }^{21}$ In our unpublished preliminary survey on endogenous testosterone secreted by TM3 cells, we found that testosterone is increased in secretion between 50 to $500 \mathrm{nmol} \mathrm{l}^{-1}$ of exogenous supplementation of testosterone. A time-dependant increase in secretion under $100-\mathrm{nmol} 1^{-1}$ supplementation of testosterone was found in cells from 6 to $48 \mathrm{~h}$ (60$96 \mathrm{ng} \mathrm{dl}^{-1}$ ). In the in vitro study, the testosterone supplementation could modulate intracellular testosterone production that was not through hypothalamus-pituitary gland-testis axis, and may be modulated via ROS signaling pathway or non-genomic signaling pathway.

According to our prestudy expectations, the existence of cell viability protection, however minimal, was found to be generated by estradiol. 17beta-estradiol was shown to have protective roles in aged testes by increasing superoxide dismutase activity and decreasing the activity of testicular enzymes. ${ }^{22}$ Blockade of estrogen receptor (with the estrogen receptor antagonist, ICI 182780) was used in this study. On the other hand, we found the approximately 20 and $40 \%$ reduction in cell viability in testosterone deprivation TM3 culture and in human ovarian granulosa cells treated with $40-\mathrm{nmol}^{-1}$ testosterone (unpublished data), respectively, showing that the protective effects of lowdose testosterone are specific to Leydig cells. Similarly, Kilinc et al. identified increased oxidative stress with androgen deprivation of the testes. ${ }^{23}$ A protective effect was demonstrated for low-dose testosterone supplementation; reduced oxidative damage and ROS generation were identified in low-dose testosterone $\left(100 \mathrm{nmol}^{-1}\right)$-manipulated cells. There was a 1.72-fold increase in ROS generation in the $500 \mathrm{nmol}$ $1^{-1}$ versus $100 \mathrm{nmoll}^{-1}$ testosterone-supplemented culture. Testicular cell apoptosis increases with age, producing accelerated germ cell loss. ${ }^{24}$ This increase in apoptosis is related to a fall in testosterone levels, and a more intense increase in lipofuscin granules, which may be indicative of oxidative stress, which occurs in these tissues. Testosterone supplementation was found to reverse the changes (both in apoptosis and lipofuscin contents in tissues), suggesting a role of androgens in these processes. ${ }^{24}$

In this study, increased lipid peroxidation was also found in $\geqslant 200$ nmol $1^{-1}$ testosterone-treated cells. Membrane phospholipids are important mediators in a variety of signal transduction processes. ${ }^{25}$ Lipid peroxidation induces membrane disturbances and damage, and its products are known to induce the generation of various cytokines and cell-signaling molecules. ${ }^{25}$ Membrane lipid peroxidation and oxidative modification of various membranes and associated proteins (e.g., receptors, ion transporters, channels, signal transduction and cytoskeletal proteins) occur in a range of degenerative disorders.

The current study was initiated to establish a functional link between excess oxidative stress and age-related declines in steroidogenesis. ${ }^{26}$ The first and rate-limiting step in the biosynthesis of steroid hormones is the transfer of cholesterol into mitochondria, which is facilitated by StAR. Functional and respiratory mitochondria with an intact mitochondrial membrane potential $\left(\Delta \Psi_{\mathrm{m}}\right)$ were demonstrated to facilitate StAR function and Leydig cell steroidogenesis; treatment of Leydig cells with hydrogen peroxide acutely inhibited steroidogenesis, reduced StAR and 3 $\beta$-hydroxysteroid dehydrogenase protein levels, and disrupted mitochondrial functions. ${ }^{27}$ In addition, Diemer et al. reported that ROS disrupted mitochondrial function in MA-10 Leydig cells, enhanced cellular apoptosis, and inhibited steroidogenesis ${ }^{5}$. Antioxidant supplementation can protect cultured mouse TM3 Leydig cells from $\mathrm{H}_{2} \mathrm{O}_{2}$-induced oxidative stress, increase cell viability due to decreased lipid peroxidation and increase testosterone production. ${ }^{28}$ This is consistent with our findings, of an approximately 1.58 fold increase in StAR expression found in low ROS-generating cells with 50-nmol $1^{-1}$ testosterone treatment. StAR expression was reduced to $69.2 \%$ in $1000-\mathrm{nmol}^{-1}$ testosterone-treated cells according to the real-time PCR analysis $(P=0.025)$. In this study, we demonstrate that treatment of testosterone can induce the expression of steroidogenesis enzymes and promotion of testosterone biosynthesis. Therefore, low-dose testosterone supplementation may contribute to improving the steroidogenic capacity of Leydig cells in older males.

In addition, Leydig cells are a target for their own steroid product, testosterone, and thus could be subject to short-loop feedback regulation by androgens. The effects of testosterone are mediated through its receptor (AR), the levels of which are, in turn, regulated by androgen. ${ }^{29}$ In 
this study, a 1.26-fold increase in AR expression was found in reduced ROS-generating cells treated with low-dose $\left(100 \mathrm{nmol}^{-1}\right)$ testosterone. AR expression was reduced to $95 \%$ in $500-\mathrm{nmol}^{-1}$ testosterone-treated cells and remained parallel with the control group.

Another unpublished survey on the effect of inert steroid, epitestosterone, showed little effect (10.2\% reduction) on cell viability in 100 -nmol $\mathrm{l}^{-1}$ epitestosterone treated cells for $48 \mathrm{~h}$. As for ROS generation, the epitestosterone showed similar effect to testosterone. Protective effects were noted after treatment with epitestosterone on TM3 cells. However, the ROS generation increased while the concentration more than $10 \mu \mathrm{mol} \mathrm{l}^{-1}$ compared to lower doses of epitestosterone treatment. These findings indicated that even inert steroid might have some effects on the Leydig cells.

Hypoxic stress was found to induce degeneration and sloughing of spermatogenic cells, to change Leydig cell populations, and to alter testis development. ${ }^{30}$ Leydig cells in testicular tissues significantly decreased in the posthypoxic period. HIF-1 is the main transcriptional factor activated by hypoxia and helps cells adapt to hypoxia. ${ }^{31} \mathrm{CoCl}_{2}$ can activate HIF-1 via stabilization of its alpha subunit (HIF-1 $\alpha$ ) at the protein level and is widely used as a hypoxia-mimicking agent. In this study, $\mathrm{CoCl}_{2}$-induced HIF- $1 \alpha$ stabilization was reduced to $78 \%$ in $100-\mathrm{nmoll}^{-1}$ testosterone-treated cells compared to the control group $(0.79 \pm 0.05, P<0.05)$. Therefore, testosterone supplementation was demonstrated to attenuate hypoxic stress in this study.

Taken together, our findings suggest that low-dose testosterone supplementation can play a beneficial role in reducing ROS generation and oxidative damage, contributing to HIF- $1 \alpha$ stabilization and activation, and enhancing steroidogenesis; those are also the main ROS generation pathways involved in age-related alteration of male infertility. ${ }^{10} \mathrm{On}$ the other hand, higher doses $\left(\geqslant 500 \mathrm{nmol} \mathrm{l^{-1 }}\right)$ demonstrated different results. Clinically, the proper application of testosterone replacement therapy is of great concern. In the future, molecular identification of different ROS generators and steroidogenesis, and its cyto-effects via genomic effects and non-genomic signaling in testosterone-treated Leydig's cells, should be further investigated.

\section{CONCLUSIONS}

This study demonstrated that low-dose testosterone serves as a protective agent in cultured Leydig's cells. However, concentrations of $\geqslant 500 \mathrm{nmoll}^{-1}$ had opposite effects. To our knowledge, this is the first paper discussing the dose effects of testosterone administration on Leydig's cells. Although further investigations of the mechanism governing the differential effects of testosterone treatment are needed, our in vitro results provide the first clues for further animal and clinical tests and shed light on testosterone replacement therapy.

\section{AUTHOR CONTRIBUTIONS}

TIH and SHK participated in the design and concept formation of this study. TLL, SYL, YC Lai, and SHK performed the experiments and acquisition of the data. TIH, JFL, YC Lin and SHK performed data analysis. TLL, SYL, YC Lai and SHK drafted the manuscript. TIH, JFL and YC Lin did the major revisions of the manuscript. TIH and SHK approved the manuscript finally.

\section{COMPETING FINANCIAL INTERESTS}

The authors declared no competing financial interests.

\section{ACKNOWLEDGMENTS}

This study was financially supported by the Shin Kong Wu Ho-Su Memorial Hospital (SKH-TMU-93-43).
1 Saad F, Gooren L. The role of testosterone in the metabolic syndrome: a review. J Steroid Biochem Mol Biol 2009; 114: 40-3.

2 Lin YM, Liu MY, Poon SL, Leu SF, Huang BM. Gonadotrophin-releasing hormone-I and -II stimulate steroidogenesis in prepubertal murine Leydig cells in vitro. Asian J Androl 2008; 10: 929-36.

3 Hermann M, Berger P. Aging of the male endocrine system. Rev Physiol Biochem Pharmacol 1999; 139: 89-122.

4 Vermeulen A, Kaufman JM. Ageing of the hypothalamo-pituitary-testicular axis in men. Horm Res 1995; 43: 25-8.

5 Diemer T, Allen JA, Hales KH, Hales DB. Reactive oxygen disrupts mitochondria in MA-10 tumor Leydig cells and inhibits steroidogenic acute regulatory (StAR) protein and steroidogenesis. Endocrinology 2003; 144: 2882-91.

6 Skjaerpe PA, Giwercman YL, Giwercman A, Svartberg J. Androgen receptor gene polymorphism and sex hormones in elderly men: the Troms $\varnothing$ study. Asian J Androl 2009; 11: 222-8.

7 Chen H, Cangello D, Benson S, Folmer J, Zhu H et al. Age-related increase in mitochondrial superoxide generation in the testosterone-producing cells of brown Norway rat testes: relationship to reduced steroidogenic function? Exp Gerontol 2001; 36: 1361-73.

8 Rose G, Passarino G, Franceschi C, de Benedictis G. The variability of the mitochondrial genome in human aging: a key for life and death? Int J Biochem Cell Biol 2002; 34: 1449-60

9 Esposito LA, Melov S, Panov A, Cottrell BA, Wallace DC. Mitochondrial disease in mouse results in increased oxidative stress. Proc Natl Acad Sci USA 1999; 96 4820-5.

10 Desai N, Sabanegh E Jr, Kim T, Agarwal A. Free radical theory of aging: implications in male infertility. Urology 2010; 75: 14-9.

11 Gooren LJ. Androgens and male aging: current evidence of safety and efficacy. Asian J Androl 2010; 12: 136-51.

12 Tan RS, Culberson JW. An integrative review on current evidence of testosterone replacement therapy for the andropause. Maturitas 2003; 45: 15-27.

13 Bagatell CJ, Bremner WJ. Androgens in men—uses and abuses. N Eng/ J Med 1996 334: 707-14.

14 Somboonporn W, Davis SR. Postmenopausal testosterone therapy and breast cancer risk. Maturitas 2004; 49: 267-75.

15 Liu PY, Swerdloff RS, Veldhuis JD. Clinical review 171: the rationale, efficacy and safety of androgen therapy in older men: future research and current practice recommendations. J Clin Endocrinol Metab 2004; 89: 4789-96.

16 Ling S, Dai A, Williams MR, Myles K, Dilley RJ et al. Testosterone (T) enhances apoptosis-related damage in human vascular endothelial cells. Endocrinology 2002; 143: 1119-25.

17 Verzola D, Gandolfo MT, Salvatore F, Villaggio B, Gianiorio F et al. Testosterone promotes apoptotic damage in human renal tubular cells. Kidney Int 2004; 65 1252-61.

18 Handelsman DJ, Wishart S, Conway AJ. Oestradiol enhances testosterone-induced suppression of human spermatogenesis. Hum Reprod 2000; 15: 672-9.

19 Ahlbom E, Prins GS, Ceccatelli S. Testosterone protects cerebellar granule cells from oxidative stress-induced cell death through a receptor mediated mechanism. Brain Res 2001; 892: 255-62.

20 Parvinen M, Hurme P, Niem M. Penetration of exogenous testosterone, pregnenolone, progesterone and cholesterol into the seminiferous tubules of the rat. Endocrinology 1970; 87: 1082-4.

21 Beardsley JA, Hilton FK. Uptake in vivo of $\left[{ }^{3} \mathrm{H}\right]$ testosterone by the interstitial compartment in testes of normal adult mice. J Reprod Fert 1975; 42: 361-4.

22 Hamden K, Silandre D, Delalande C, Elfeki A, Carreau S. Protective effects of estrogens and caloric restriction during aging on various rat testis parameters. Asian $J$ Androl 2008; 10: 837-45.

23 Kilinc F, Kayaselcuk F, Aygun C, Guvel S, Egilmez T et al. Experimental varicocele induces hypoxia inducible factor-1alpha, vascular endothelial growth factor expression and angiogenesis in the rat testis. J Urol 2004; 172: 1188-91.

24 Jara M, Carballada R, Esponda P. Age-induced apoptosis in the male genital tract of the mouse. Reproduction 2004; 127: 359-66.

25 Mattson MP. Metal-catalyzed disruption of membrane protein and lipid signaling in the pathogenesis of neurodegenerative disorders. Ann NY Acad Sci 2004; 1012: 37-50.

26 Cao L, Leers-Sucheta S, Azhar S. Aging alters the functional expression of enzymatic and non-enzymatic anti-oxidant defense systems in testicular rat Leydig cells. J Steroid Biochem Mol Biol 2004; 88: 61-7.

27 Allen JA, Diemer T, Janus $\mathrm{P}$, Hales KH, Hales DB. Bacterial endotoxin lipopolysaccharide and reactive oxygen species inhibit Leydig cell steroidogenesis via perturbation of mitochondria. Endocrine 2004; 25: 265-75.

28 Chang MS, Kim WN, Yang WM, Kim HY, Oh JH et al. Cytoprotective effects of Morinda officinalis against hydrogen peroxide-induced oxidative stress in Leydig TM3 cells. Asian J Androl 2008; 10: 667-74

29 Zhu LJ, Hardy MP, Inigo IV, Huhtaniemi I, Bardin CW et al. Effects of androgen on androgen receptor expression in rat testicular and epididymal cells: a quantitative immunohistochemical study. Biol Reprod 2000; 63: 368-76.

30 Gosney JR. Effects of hypobaric hypoxia on the Leydig cell population of the testis of the rat. J Endocrinol 1984; 103: 59-62.

31 Liu JX, Du JZ. Hypoxia alters testis development in neonatal rats. Neuroendocrinol Lett 2002; 23: 231-7. 